Document downloaded from:

http://hdl.handle.net/10251/116793

This paper must be cited as:

Adam, JM.; Buitrago, M. (2018). Learning from failures in an emblematic building in Valencia, Spain. Engineering Failure Analysis. 92:418-429.

doi:10.1016/j.engfailanal.2018.06.023

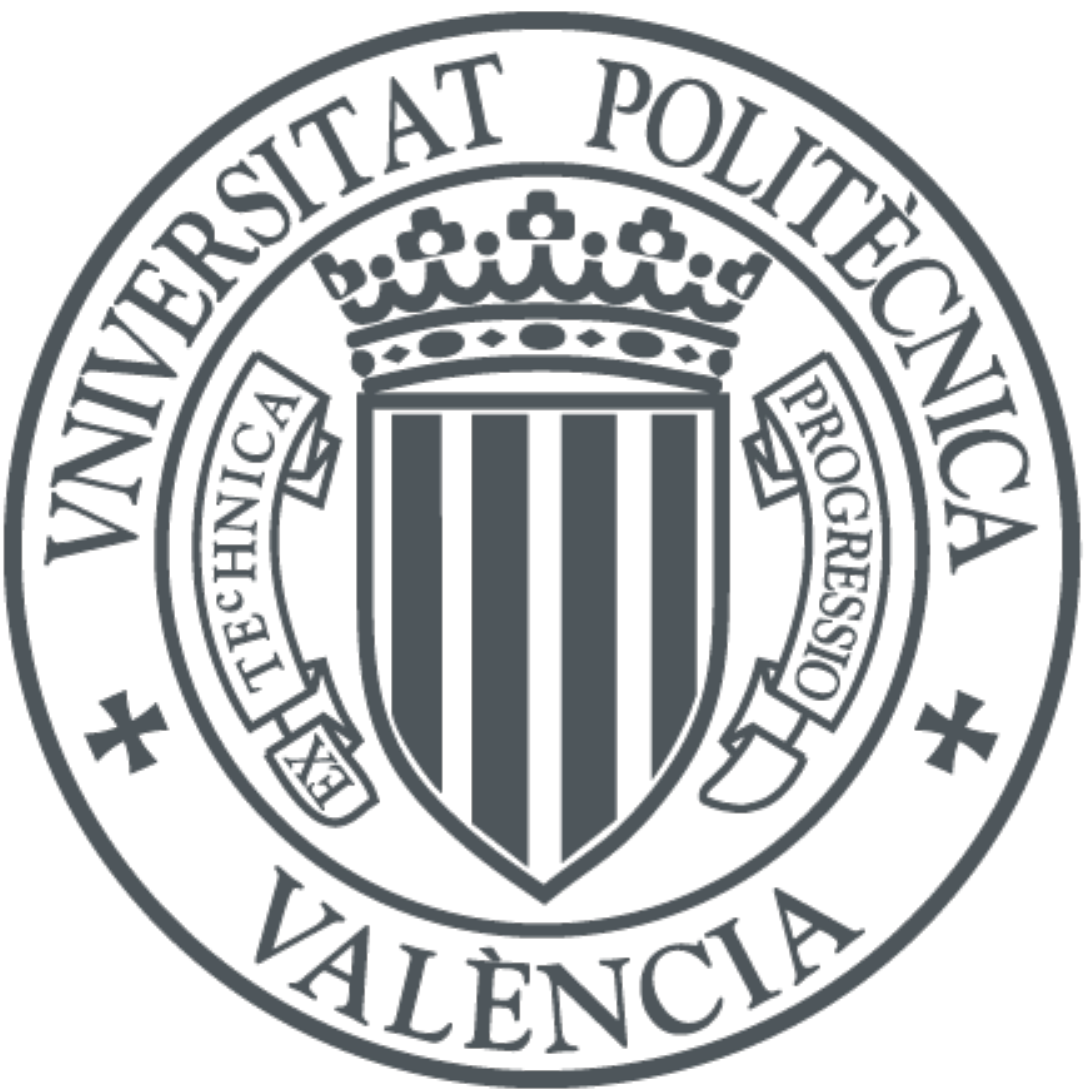

The final publication is available at

http://doi.org/10.1016/j.engfailanal.2018.06.023

Copyright Elsevier

Additional Information 


\title{
Learning from failures in an emblematic building in Valencia, Spain
}

\author{
Jose M. Adam*, Manuel Buitrago \\ ICITECH, Universitat Politècnica de València. Camino de Vera s/n, 46022 Valencia, Spain \\ * Corresponding author. Tel.: +34 963877562; fax: +34 963877568. \\ E-mail address: joadmar@upv.es (J.M. Adam).
}

\begin{abstract}
On many occasions advances have been made in science and engineering thanks to the knowledge gained from failures. In the particular case of structural engineering the study of actual failures makes it possible to advance and define new theories, concepts and designs, for example, the changes and improvements that appeared after some of the "classical" failures such as the Ronan Point building, Quebec Bridge, Murrah Federal Building, Tacoma Narrows Bridge and the World Trade Center. This paper describes a teaching method used with structural engineering students at the Universitat Politècnica de València based on the study of cases of damage to buildings in the Valencia, Spain. Due to its special characteristics, one of the buildings studied is the Príncipe Felipe Science Museum. Some of its main characteristics are: 1) it is one of Valencia's emblematic buildings, 2) its considerable dimensions required huge quantities of concrete, 3) it has a complex structure and an innovative architectural design, 4) the wide variation in the type of damage detected, which make it a particularly valuable teaching aid. The most important damage detected has been classified and described during the visits to the Príncipe Felipe Science Museum. The damage mechanisms are widely diverse and include: those due to the behaviour of the concrete itself (e.g. shrinkage and early age thermal cracking), those due to the presence of damp, those whose origin can be traced back to the construction phase, and others due to corroded reinforcement and to the loads acting on the structure. The paper has a double value since on one hand it describes a highly successful teaching aid for the training of specialists
\end{abstract}


in structural engineering, while on the other it classifies and describes the existing damage in one of the most important modern buildings in Spain and perhaps in Europe.

Keywords:

Damage; Failure; Building; Teaching; Learning; Concrete 


\section{Introduction}

Since the beginning of time, the human race has been learning from its failures in all facets of life. In the field of engineering on many occasions advances have been achieved thanks to the study of actual failures, which have made it possible to produce new theories, concepts and designs. The investigation and study of actual failures is also important for the improvement of the design and construction of structures. Due to the increased interest in the study of structural failures, there has been a significant growth of the number of conferences, journals and publications dedicated to analysing actual failures in the structural field in the last few years. The study of real failures has also been used for teaching purposes in the structural engineering field, for example in the form of the excellent studies published by Professors N. Delatte [1-4] and H. Petroski [5,6].

Within the study-analysis of what could be called "classical" cases of failure-collapse, one could point to for example those by: a) Pearson and Delatte [7] on Ronan Point; b) Pearson and Delatte [8] on the Quebec Bridge; c) King and Delatte [9] on the 2000 Commonwealth Avenue building; d) Corley et al [10], Kazemi-Moghaddam and Sasani [11], Mlakar Sr. et al [12], Osteraas et al [13], and Sozen et al [14] on the Murrah Federal Building; e) Walshe and Wyatt [15], Wyatt [16], Matsumoto et al [17], and Plaut [18] on the Tacoma Narrows Bridge; and f) Corley [19], Omika et al [20], Wang et al [21], Irfanoglu and Hoffman [22], and Miamis et al [23] on the World Trade Center. All these "classical" failures made the headlines in their day and the subsequent study of the events that led up to them helped to improve subsequent designs.

The studies published on failed structures are very wide-ranging, including for example: masonry walls [24,25], the aftermath of earthquakes in buildings [26,27], problems in bell towers due to the effect of ringing bells [28], the effect of marine atmospheres on buildings [29], damage to industrial masonry chimneys [30], water tank failures [31], the collapse of long-span roof structures [32], failures in old buildings [33], failures of building structures during construction [34] and damage to masonry domes [35]. 
At the present time two of the leading journals that specialise in publishing papers on case studies of structural failures are Engineering Failure Analysis (published by Elsevier) and the Journal of Performance of Constructed Facilities (published by the ASCE). Some of the most important of the recent papers published in Engineering Failure Analysis include: Bayuaji et al [36], Mosoarca et al [37], Otunninyi et al [38], Vatansever et al [39], and Krentoswki et al [40]. While some of those published in the Journal of Performance of Constructed Facilities include those by: Stark et al [41], Shrestha and Hao [42], Bilcik et al [43], Wang et al [44], and Yamin et al [45].

This paper deals with part of the work done by authors using the "learning from failures" philosophy both in their research and in their teaching duties at the Universitat Politècnica de València (UPV). The authors created a series of teaching routes for their students in which they could learn from failures and damage to buildings in the city of Valencia (Spain). This paper describes the work carried out during visits to one of Valencia's most emblematic buildings: the Príncipe Felipe Science Museum designed by architect Santiago Calatrava. The paper's principal novelty and contribution is due to its combining a description of one of the authors' teaching methods based on "learning from failures" with an analysis of the defects found in one of the city's, if not the world's, best known modern buildings.

After this Introduction, Section 2 describes the teaching method based on the study of actual failures used by the authors in some of their courses. Section 3 describes the special characteristics of the Príncipe Felipe Science Museum, while Section 4 analyses the main damages found to be present and the paper ends with the main conclusions drawn from the work in Section 5.

\section{Learning from structural failures at the Universitat Politècnica de València}

At the present time, the UPV's Civil Engineering School includes in its syllabus two courses that deal with the analysis of structural failures: Pathology and Rehabilitation, and Maintenance and Conservation of Structures. The Department of Construction Engineering offers Pathology 
and Rehabilitation to students of the Master's Degree in Concrete Engineering. These three subjects are designed to achieve the following objectives:

- Train students in the field of structural failures, diagnosis and remedial actions.

- Use the study of failures to consolidate the knowledge acquired in structural engineering.

- Teach techniques of management, maintenance and conservation of existing structures.

- Instil students with ethical aspects of the profession.

Within the "learning from failures" teaching method, in the three preceding courses the students will already be familiar with the teaching routes in which visits are made to a series of buildings in the city of Valencia to inspect existing damage.

Field visits are organised immediately after the corresponding theoretical concepts of damage mechanisms have been dealt with in lectures. Besides consolidating these concepts, the visits are designed to familiarise students with the inspection protocols of damaged structures. Before the visit, the professor explains the route the students will follow and the location of the structures they will inspect. These groups are composed of 15-20 students, who are further sub-divided into smaller groups of three or four. Damage is inspected in situ, photos are taken to locate the damage on a plan of the building, and the students then draw up a brief report on the main types of damage observed, indicating probable causes and its further evolution. This report is marked by the lecturer and contributes to the final grade achieved in the subject. After handing in the reports, the students debate the experience in class assisted by slides of the damage observed and are encouraged to give their ideas on its origin and evolution. The lecturers' feedback is highly satisfactory since the debates are usually quite intense with the enthusiastic participation of the whole class. There is no doubt that these activities motivate the students and help them to construct their own self-learning programs.

The routes followed are quite near the university campus and in fact one is within the campus itself and involves buildings with which the students are already familiar. Another is through one 
of Valencia's most emblematic districts, the City of Arts and Sciences. Fig. 1 shows a map of Valencia with an outline of both routes.

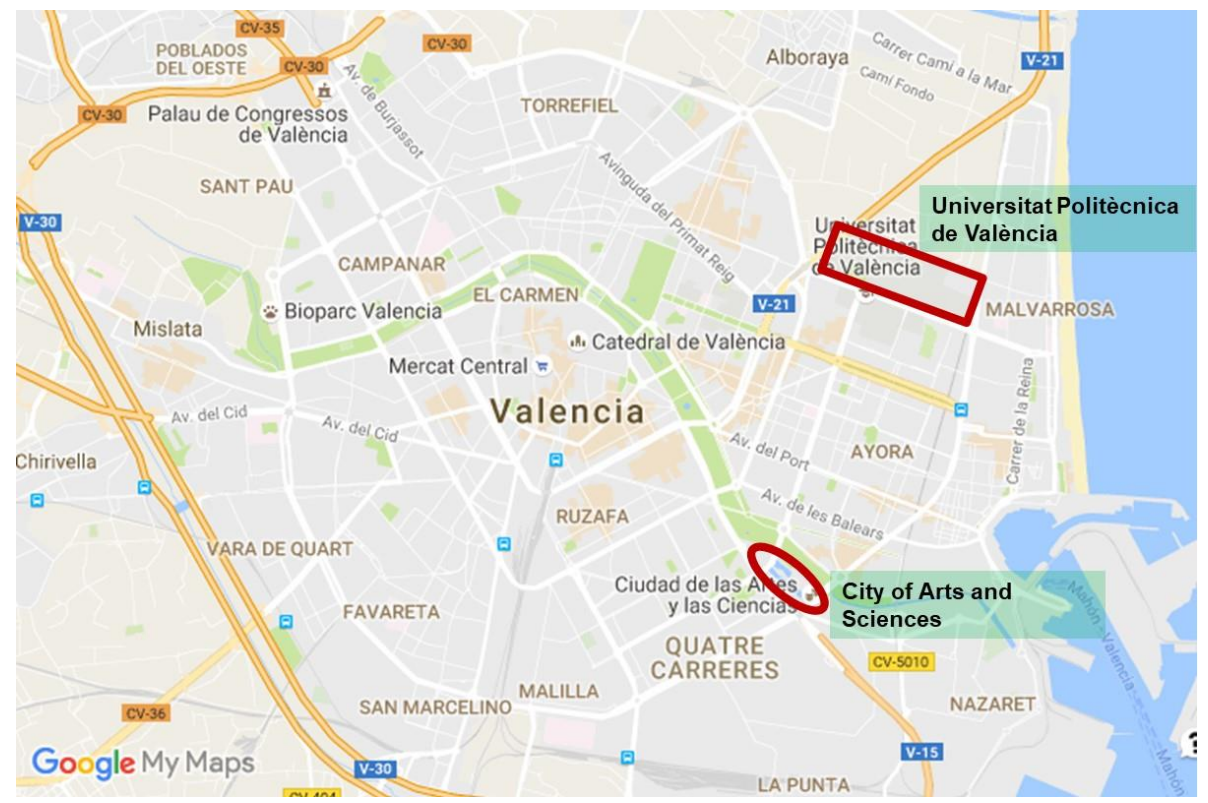

Fig. 1. View of two routes in the city of Valencia. Source: Google Maps

Fig. 2 shows the first route in the UPV campus. The buildings visited are: Department of Construction Engineering Laboratory, Students' Building, and the Sports Centre car park. Fig. 3 shows the route followed in the City of Arts and Sciences. The buildings visited are some of the city's most emblematic and include: the Palau de les Arts, the Hemisferic, the Príncipe Felipe Science Museum, and the Àgora.

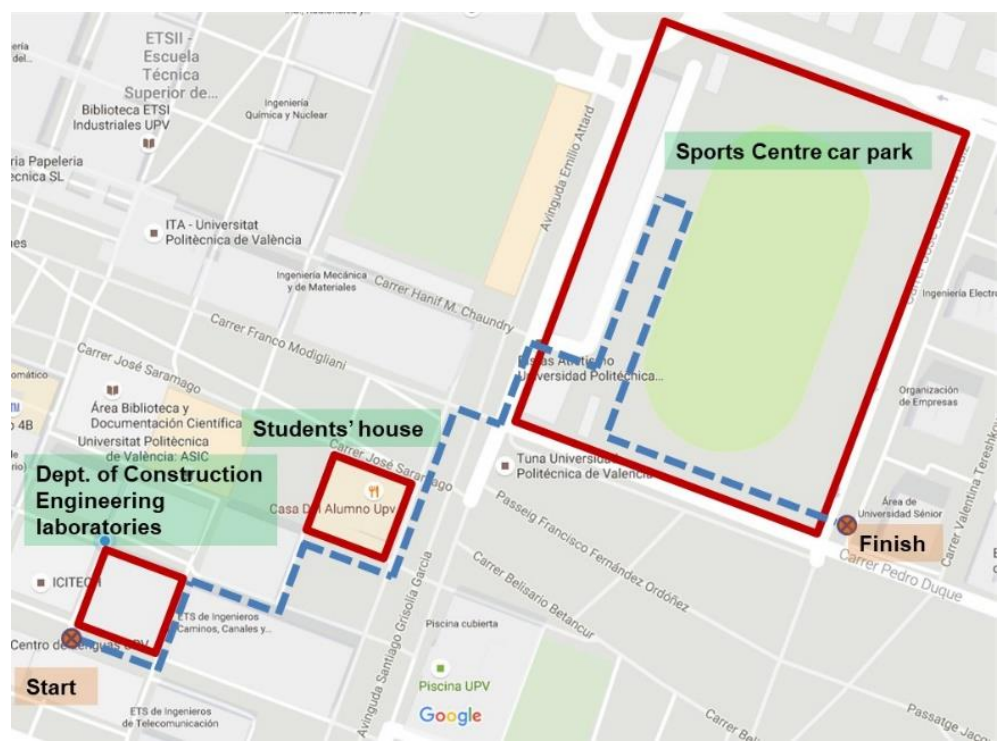

Fig. 2. Teaching route in the UPV campus. Source: Google Maps 


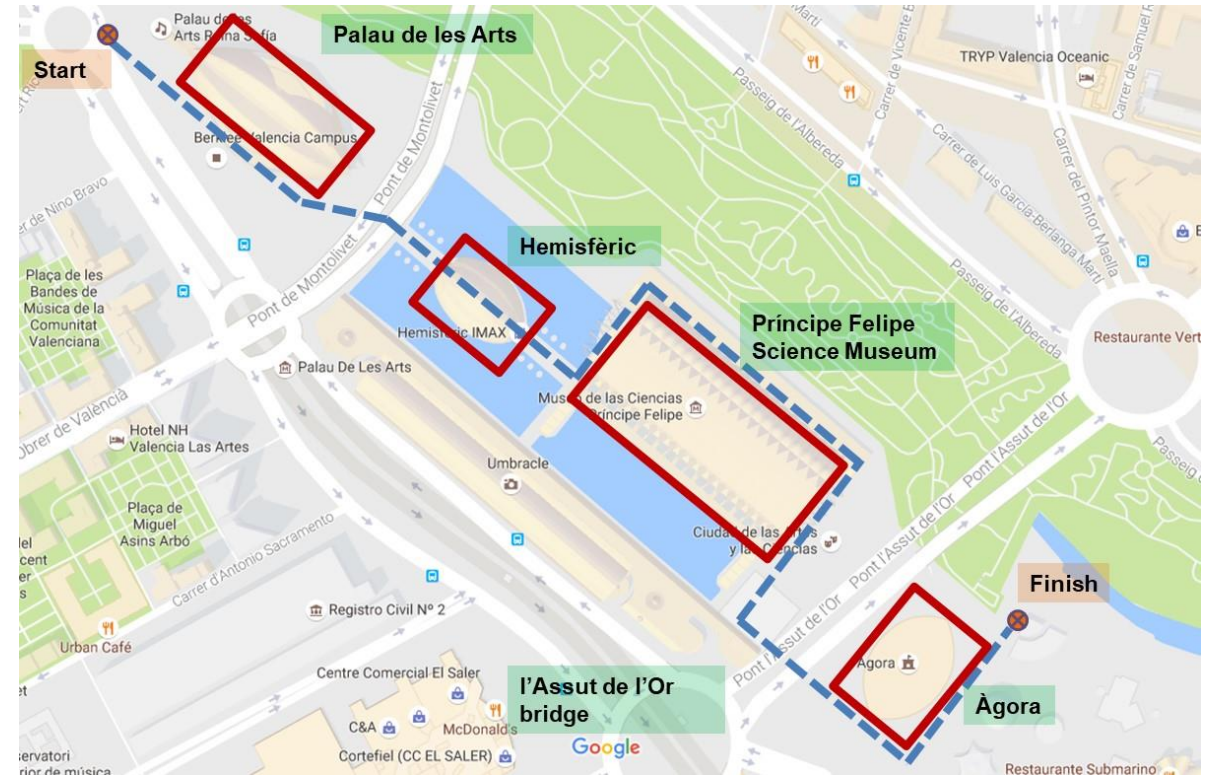

Fig. 3. Teaching route in the City of Arts and Sciences. Source: Google Maps

\section{General description of the Príncipe Felipe Science Museum}

Based on the work carried out with the students on the teaching routes, this paper describes the principal damage observed in the Príncipe Felipe Science Museum. The building under study (see Fig.4a) is part of the complex known as the City of Arts and Sciences, whose buildings include: the Hemisfèric, the Príncipe Felipe Science Museum, the Umbracle, the Oceanográfic, the Palau de las Arts, the Assut de l'Or Bridge, and the Àgora.
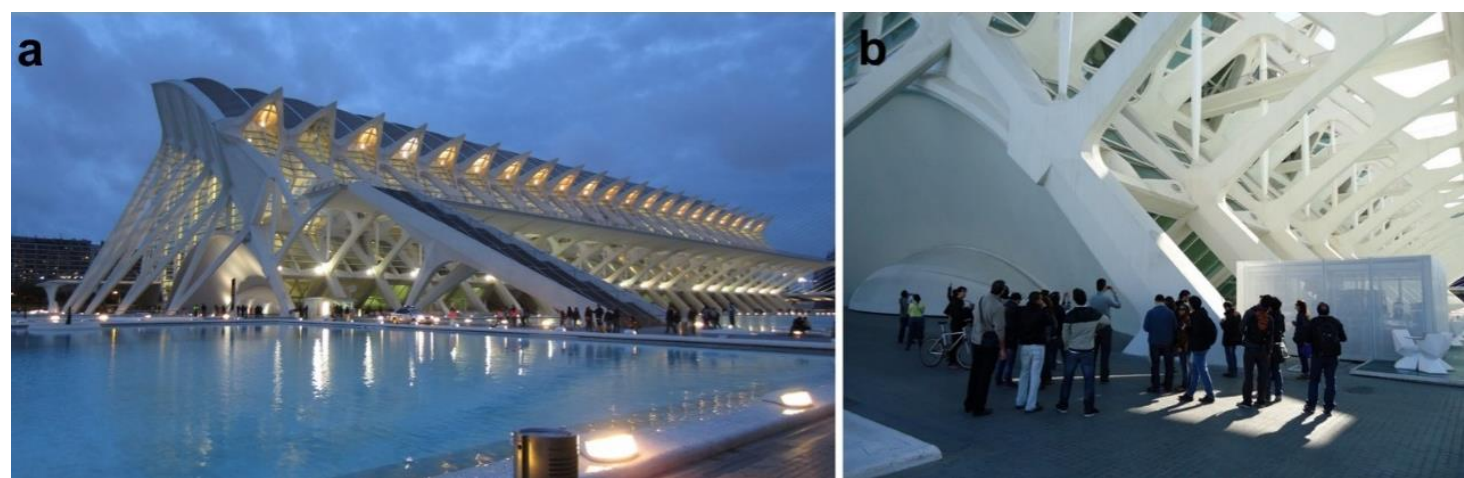

Fig. 4. a) General view of the Príncipe Felipe Science Museum; b) Group of students on a field visit.

The Príncipe Felipe Science Museum was designed by the well-known architect Santiago Calatrava and was opened in the year 2000. It has a constructed area of approximately $42,000 \mathrm{~m}^{2}$, measures $220 \mathrm{~m}$ long by $80 \mathrm{~m}$ wide and reaches a height of $55 \mathrm{~m} .58,000 \mathrm{~m}^{3}$ of concrete and 
14,000 tons of steel were used in its construction. Further information on the building can be obtained at the City of Arts and Sciences website [46].

This museum has become one of the symbols of the city of Valencia due to its great architectural value and has attracted the interest of the local population as well as the many tourists who visit the city. In fact, it is one of Valencia's most visited buildings. Its design and construction were quite a challenge for both architects and engineers. Its innovative architectural design and geometry involve a complex structure built with a combination of concrete and steel.

The building's impressive size, the large volumes of concrete it required, and the complexity of its structure make it an ideal place to find some of the most common types of damage to reinforced concrete structures. The field visits to the museum make a valuable contribution to the training of the students, who greatly enjoy visiting one of the city's most symbolic buildings. Fig.4b shows a group of students on a field visit.

\section{Analysis of damage observed in the Príncipe Felipe Science Museum}

Of all the field visits included in the route, the students are most enthusiastic about one to the Príncipe Felipe Science Museum, and this is probably the visit that contributes most to their training as regards damage to reinforced concrete structures. As the building is of large dimensions and large volumes of concrete were used in its construction, there is a greater chance of finding defects there than in other types of building. And another important aspect from the students' point of view is that the damages found there are due to a wide variety of causes.

The main types of damage observed in the building are described and classified below. It should be pointed out that the building is situated within $1 \mathrm{~km}$ from the sea and subject to an environment with a high chlorides content, and while most of the damages found may affect its durability they do not pose any grave risk to the structure itself.

\subsection{Damp}

Damp patches can be seen in some parts of the building due to leaks. Even though these patches are not dangerous in themselves, they do generate unsightly and perhaps inadmissible 
colour changes in a building with such high aesthetic value, and the presence of damp could cause long-term durability problems.

Some damp patches can be seen in column-slab joints in Fig.5. These joints have the special characteristic that the columns are not actually connected to the slab and their insufficient waterproofing means that the rain running down the columns creates these stains. Damp patches can also be found in some wall-slab joints, such as those in Fig.6, or where stairs are joined to slabs, as seen in Fig.7.
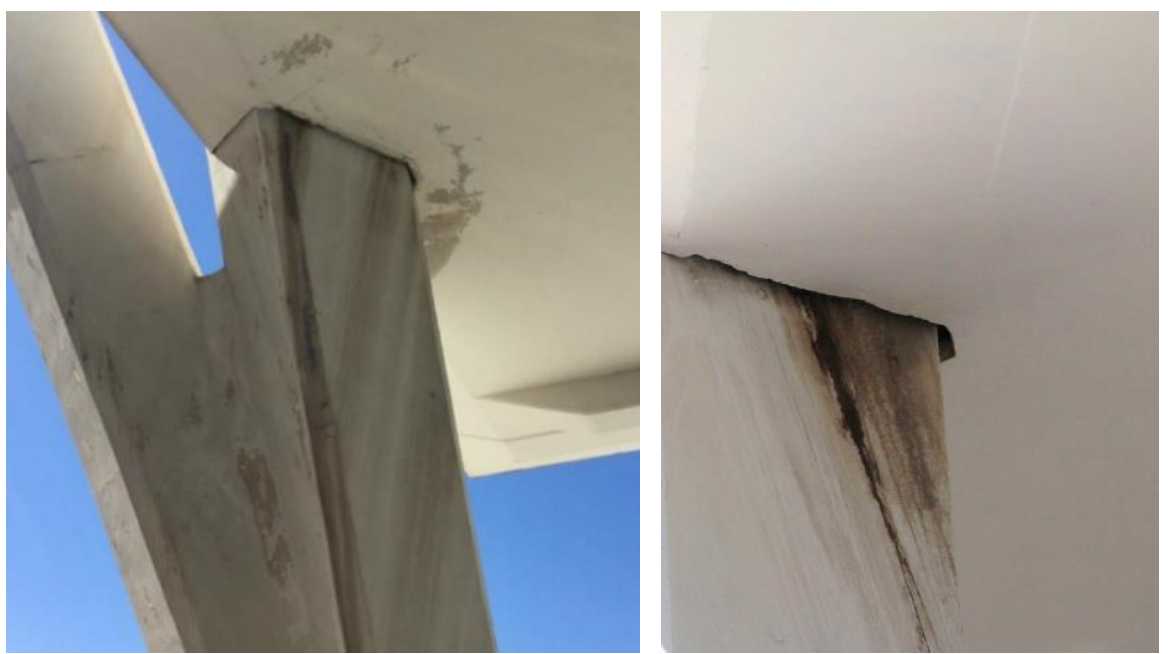

Fig. 1. Damp patches in column-slab joints
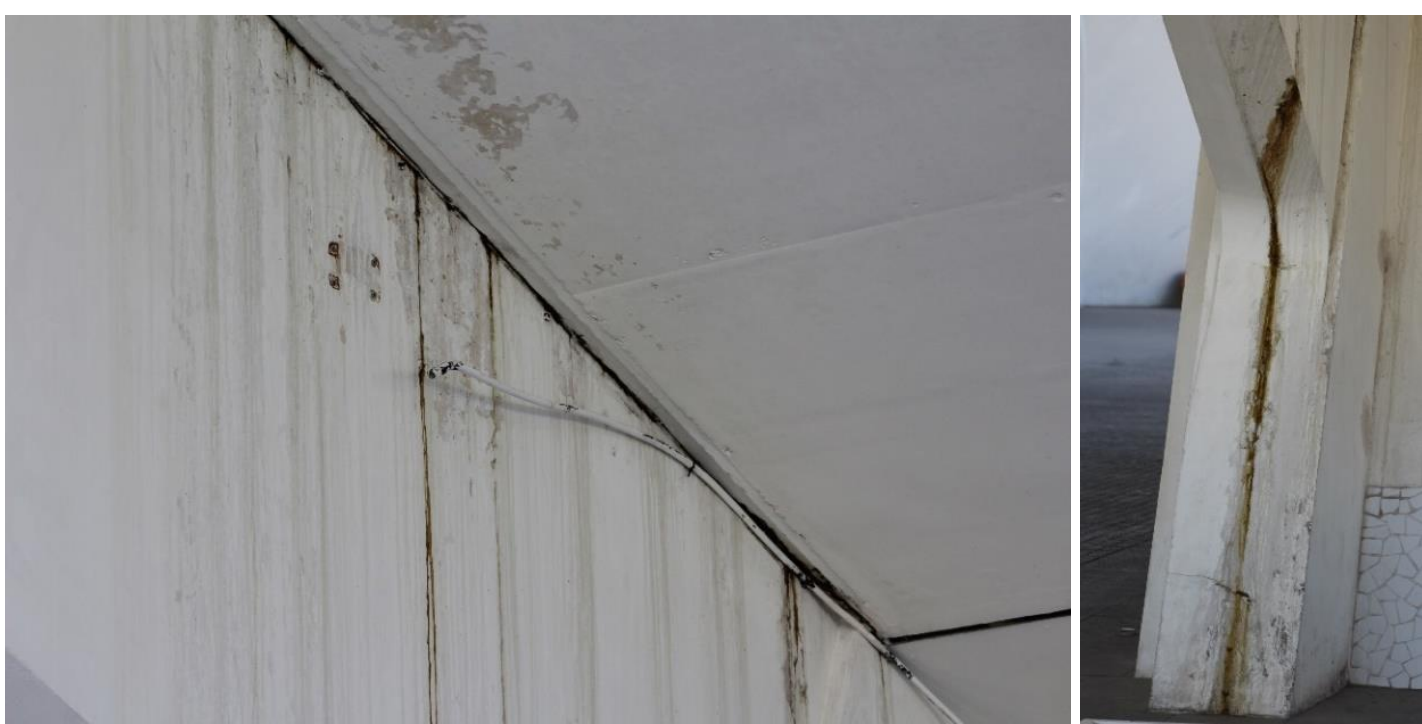

Fig. 2. Damp in wall-slab joint (left) and on base of wall (right) 


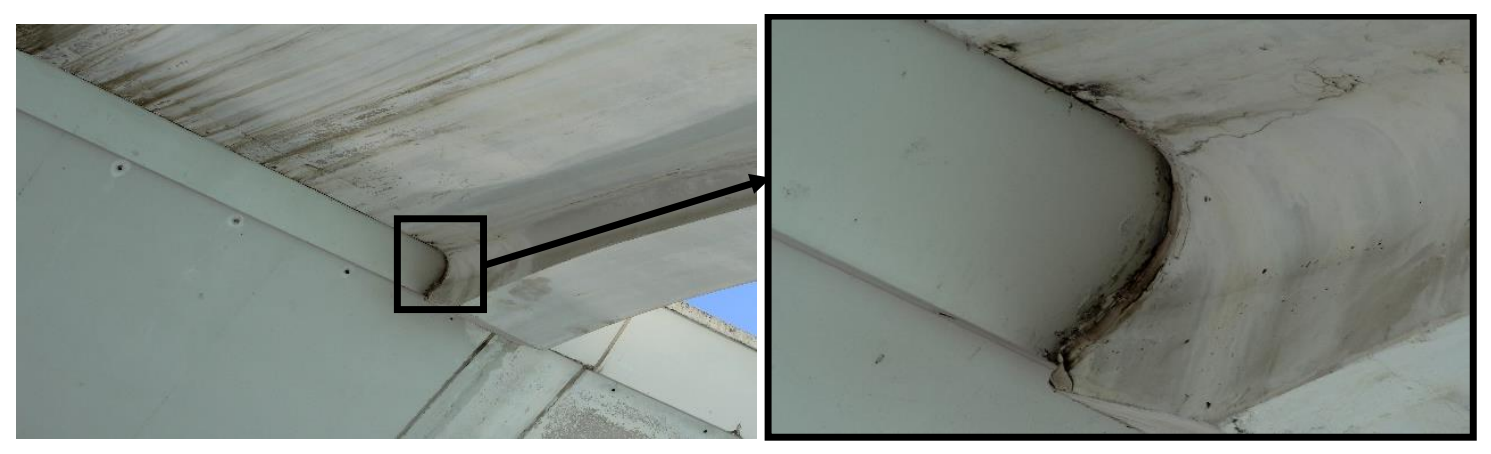

Fig. 3. Damp in stairs-slab joint (left) with detail of most affected zone (right)

Damp can also be seen close to some waste water pipes (see Fig.8). The position of some down-pipes allows the rain to run down the concrete surfaces, leaving stains, with subsequent aesthetic and durability problems.
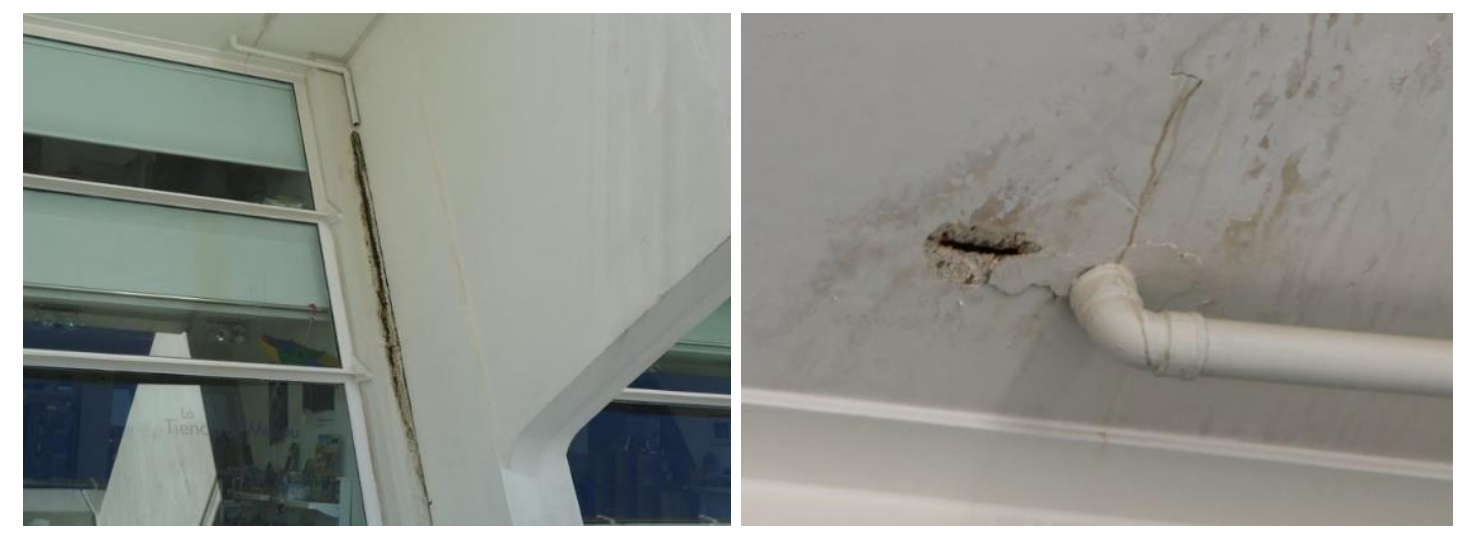

Fig.8. Deficient rain drainage on exterior wall. Generation of aesthetic defects (left) and corrosion of reinforcement (right)

There is a general problem of damp in the concrete facings and is not only found in the cases cited above. Many cracks have appeared on surface elements such as reinforced slabs and walls accompanied by the presence of dampness. Fig.9 shows a floor slab with cracks through which rain has leaked. The rainwater has dissolved oxide from the reinforcement and left stains on the surface of the concrete. Fig.10 shows another slab zone where rainwater has passed through the cracks leaving calcium carbonate deposits similar to the stalactites found in underground caves. 


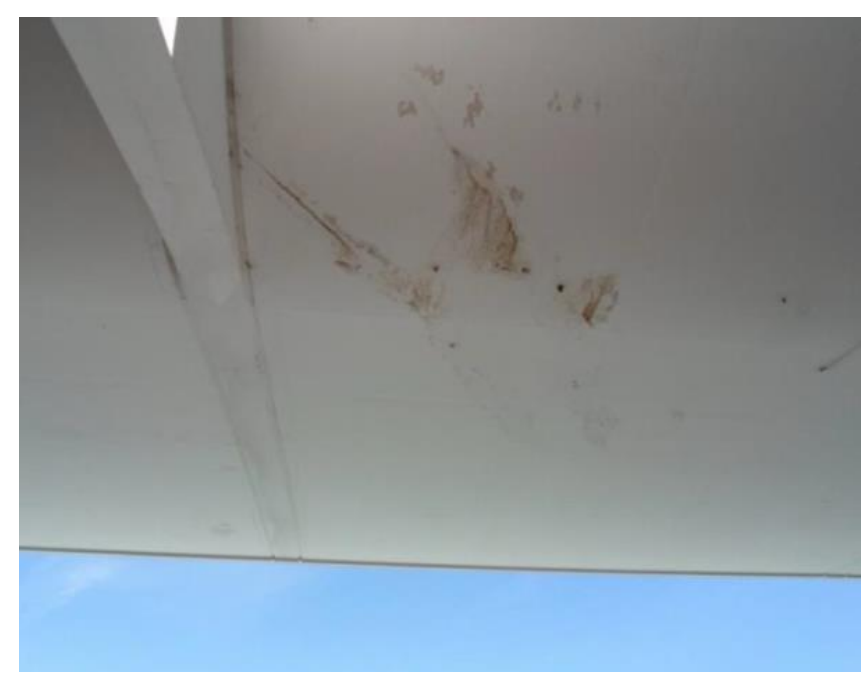

Fig.9. Rust stains due to water leaking through a floor slab
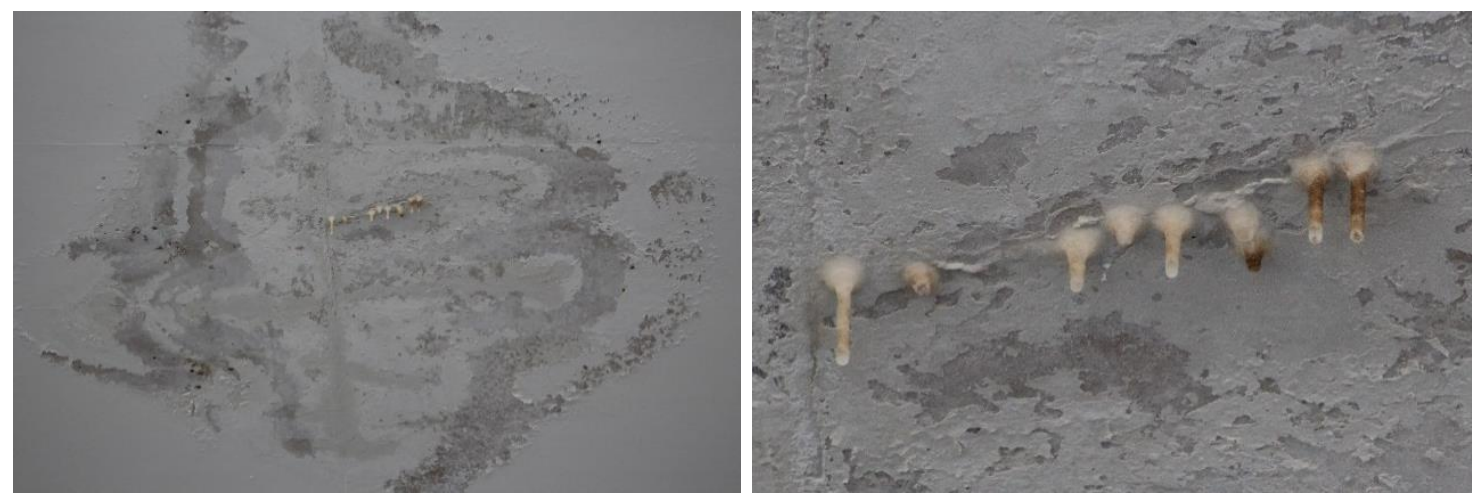

Fig. 10. Calcium carbonate deposits in the form of "stalactites"

\subsection{Porous concrete surfaces}

Fig. 11 shows surface pores in a cornice and column, due in both cases to shortcomings in the construction phase. Both these elements are inclined at an angle of less than $90^{\circ}$ to the horizontal. The presence of pores in Fig. 11 (left) is due to the inadequate contact of the fresh concrete with the formwork. Because of the inclination of the formwork, the pressure of the concrete on the formwork may have been low, allowing air bubbles to form between both these elements. On the other hand, Fig. 11 (right) shows a defect that is repeated in almost all the columns along one façade and that appears to be due to a formwork problem that left pores on one of the column faces. 

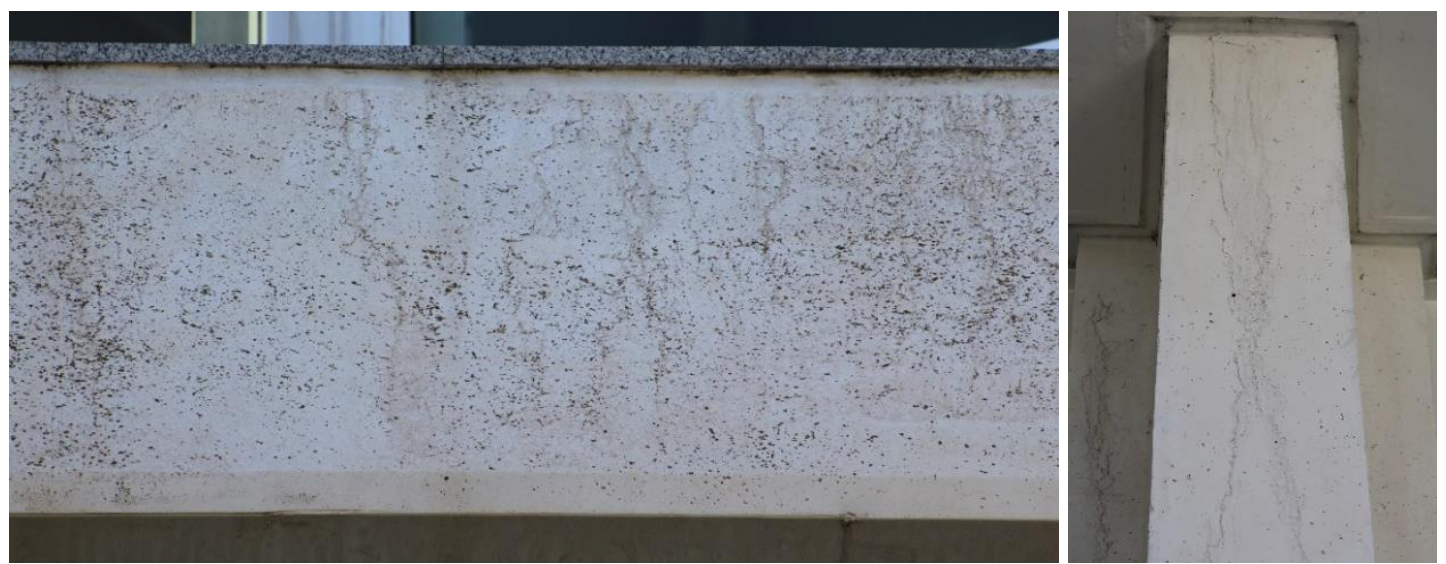

Fig.11. Surface pores in cornices (left) and columns (right)

\subsection{Corrosion of reinforcement}

The presence of corrosion has been detected in the reinforcement of many elements and zones of the building. For example, Fig. 12 shows the result of corroded reinforcement in a column due to insufficient concrete cover. These situations need to be repaired, as corroded reinforcement causes the steel to swell, which in turn causes peeling of the concrete cover. This type of damage can have serious effects on structural durability due to the building being little more than $1 \mathrm{~km}$ from the sea.

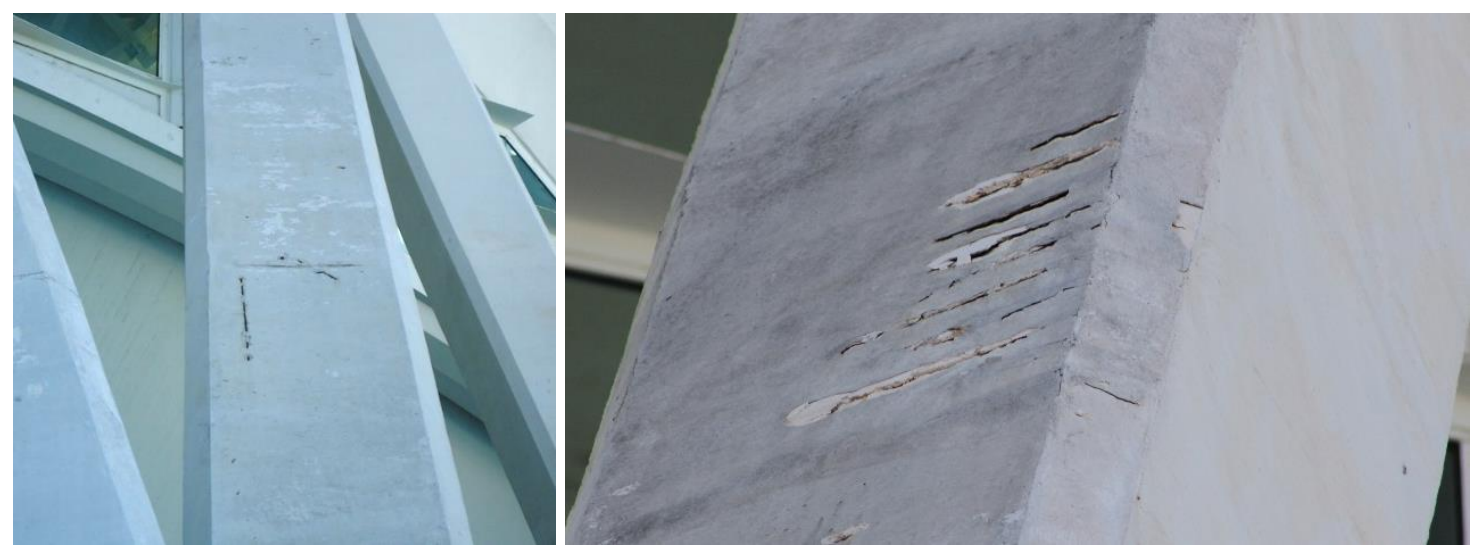

Fig. 12. Corrosion of column reinforcement

\subsection{Cracks in walls}

One of the defects that appear repeatedly on the external reinforced concrete walls of the museum is due to early age thermal cracking of the concrete, which causes cracks starting from the base. Due to the cement hydration reactions shortly after pouring, the temperature rises in the concrete and when it cools down again it tends to contract. However, as the contraction is 
constrained at the base of the wall due to the foundations, the tensile forces caused by this effect are transformed into cracks such as those shown in Fig.13.
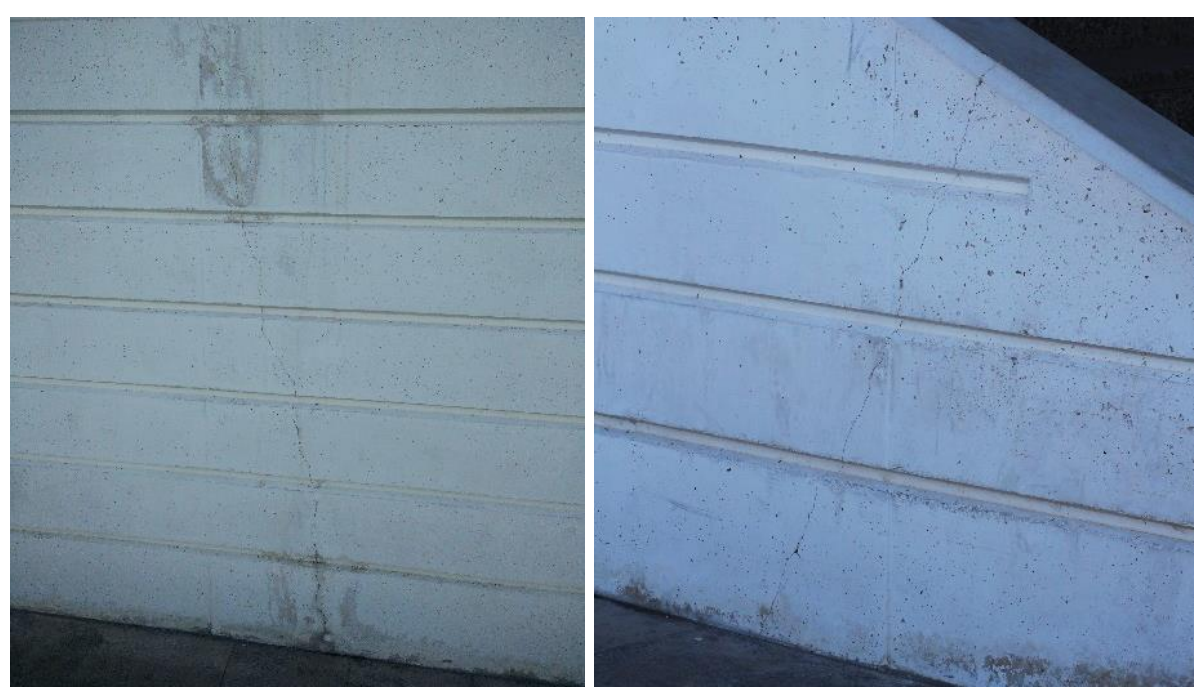

Fig.13. Early age thermal cracking in a wall

\subsection{Cracking in cornices}

Some of the cornices present cracks perpendicular to the edge, as shown in Fig.14. As these are quite wide, they are highly visible. Considering the dimensions of these elements and the position of the cracks, concrete shrinkage can be considered as a likely cause. Since these types of crack can be deep, the structure's durability may be significantly affected.
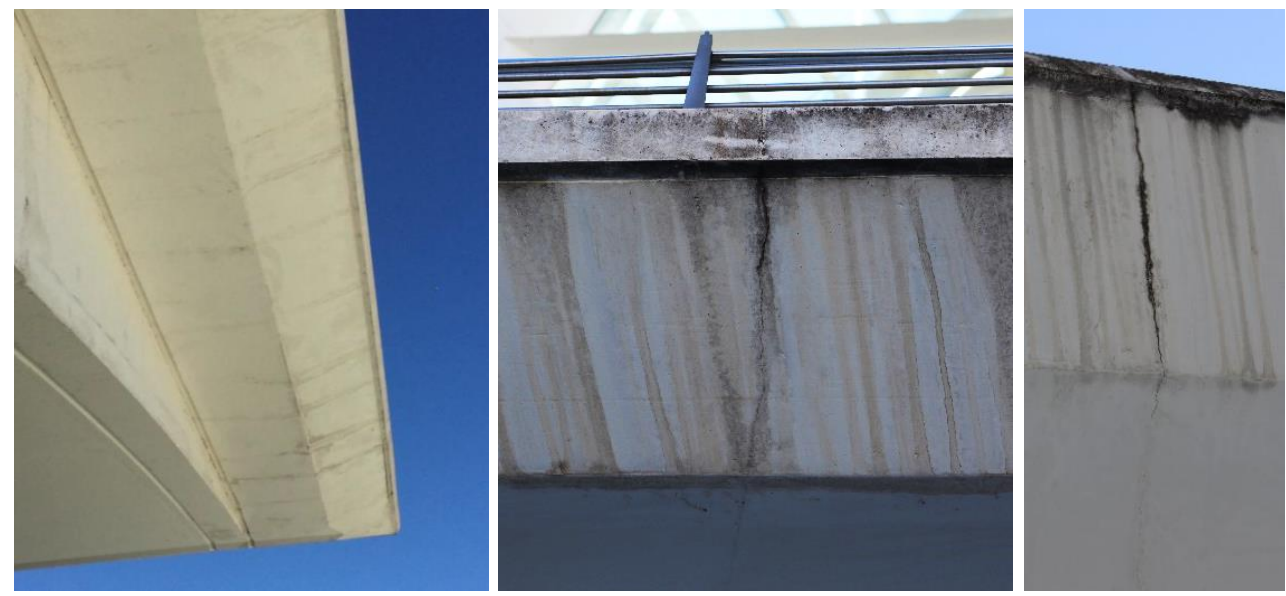

Fig.14. Cracked cornices

\subsection{Cracks in cantilevers}

In one of the building's façades there are large concrete slabs resting on cantilever beams, as seen in Fig.15 (left). The entire volume of these beams presents a serious degree of cracking, 
which is due to negative bending moments in their upper face. In many cases the cracks are accompanied by rust stains. The cracks are also considerably wide and, in some cases, reach to more than half the depth of the beam. Apart from their effects on the structure, these cracks can also seriously reduce the durability of the concrete and its reinforcement.
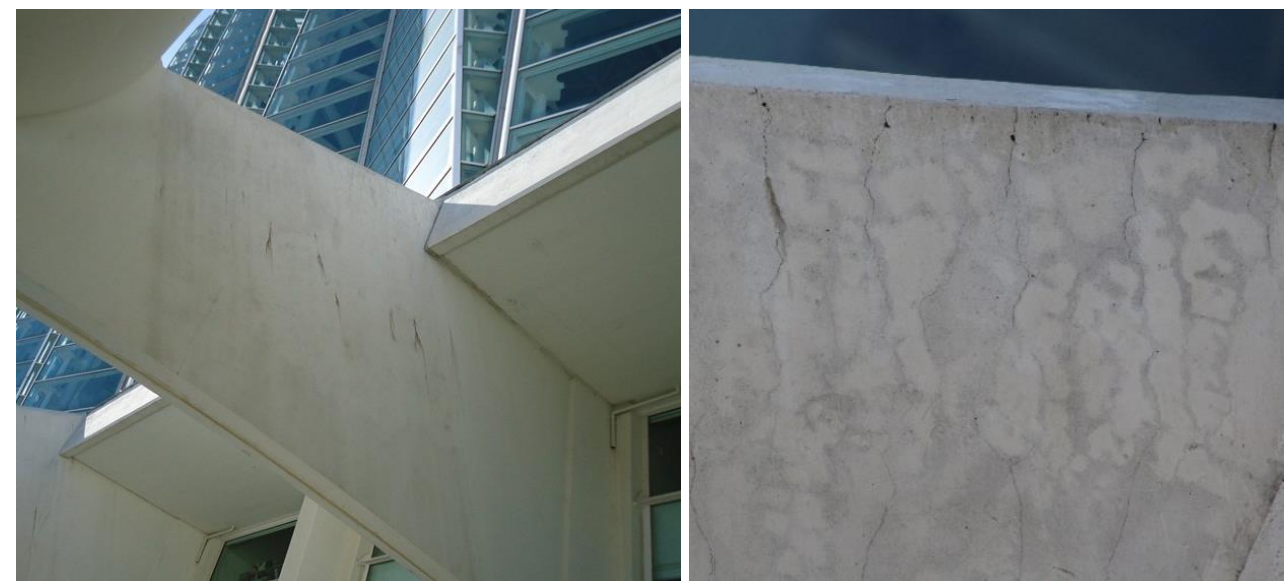

Fig.15. Cracks in cantilever beams

Another type of cracking can be seen in the cantilevered deck, as shown in Fig.16. These cracks can be seen from the ground, which gives an idea of their size, which clearly compromises the structure's service life. Some of the cracks have damp patches due to the penetration of rain water.
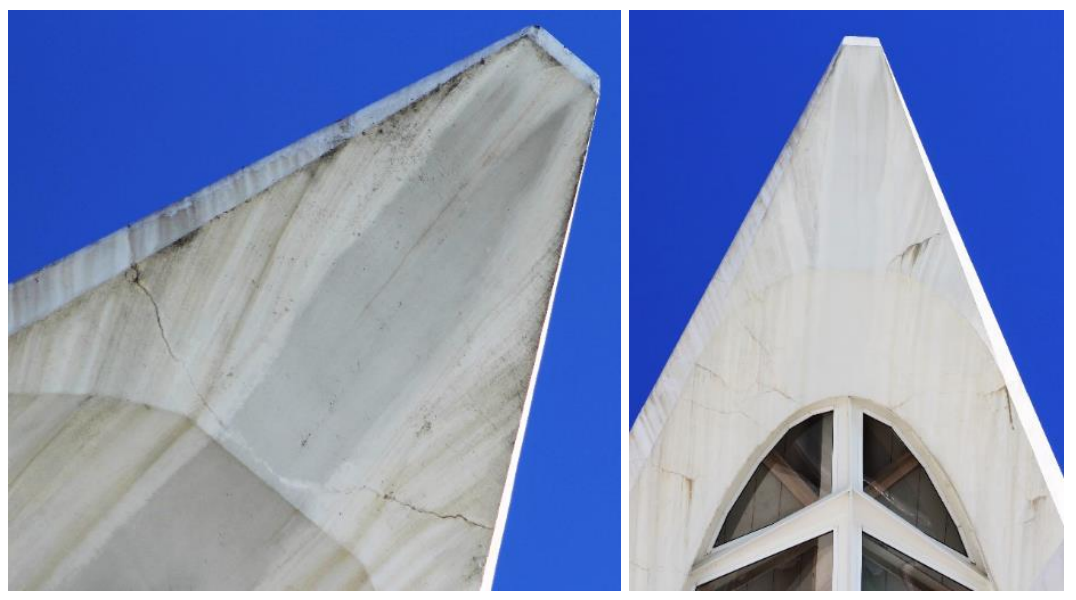

Fig.16. Cracks in the deck cantilever

\subsection{Map cracking}

Some concrete surfaces show the effects of what is known as "map cracking" (see Fig.17), which can appear in very young concrete due to the evaporation of its water content after pouring, 
possibly followed by inadequate curing. Although the cracks thus formed are normally shallow and are not serious, they can affect structural durability.
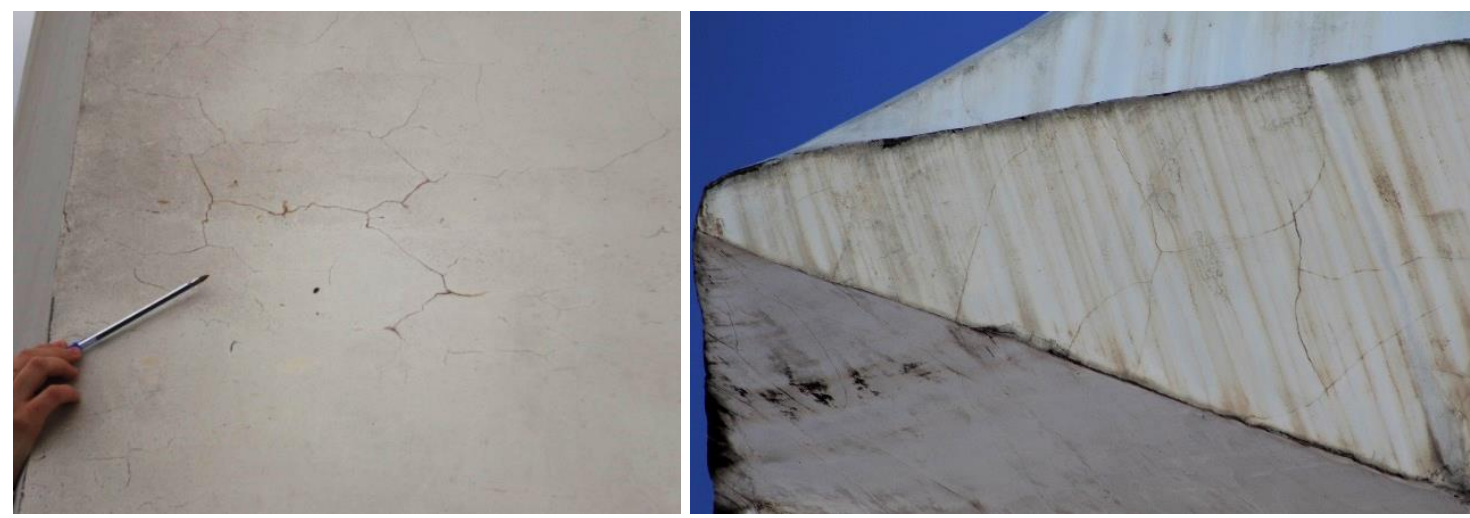

Fig.17. Map cracking

\subsection{Cracks in joints between two columns}

Fig. 18 shows a view of cracks in the joint between two columns on the front of the building. The columns are not vertical and meet over the foundations. The compressive load on the columns generates horizontal tensile forces in the joint and triggers the vertical cracks seen in Fig.18.
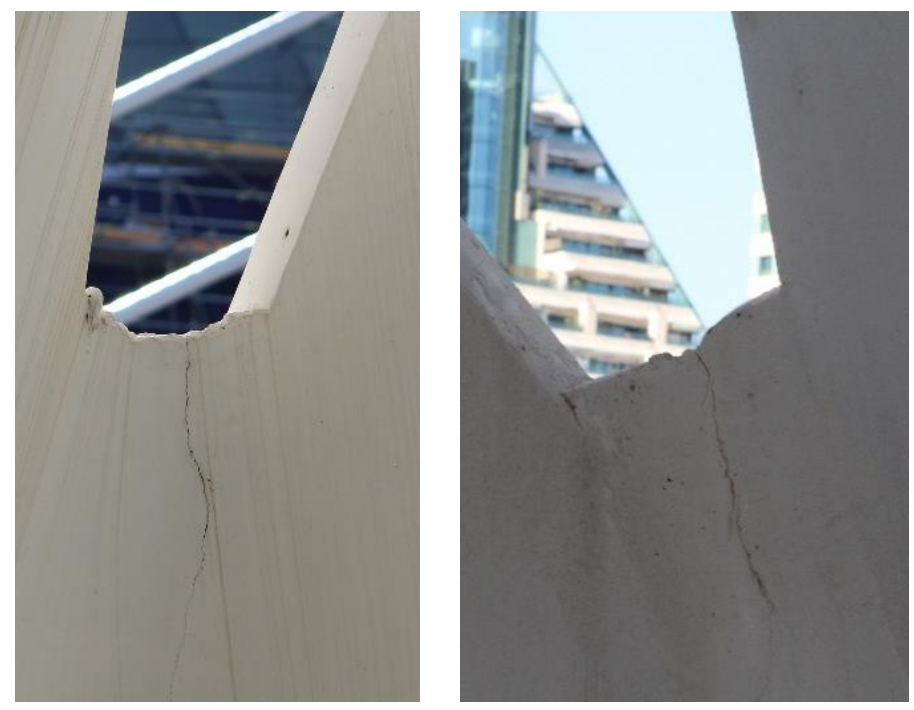

Fig.18. Cracks at the point where two columns meet

\subsection{Column deformation}

There are ten out-of-vertical columns at the front and back of the building which can be seen with the naked eye to be deformed with respect to their axes (Fig.19). The reason for this deformation is unclear and would require an in-depth study. Plausible causes could include 
formwork distortion during the construction of the columns or the columns' own self-weight. Under heavy compressive loads, this deformation could generate load eccentricity that would increase the bending moment on the column.
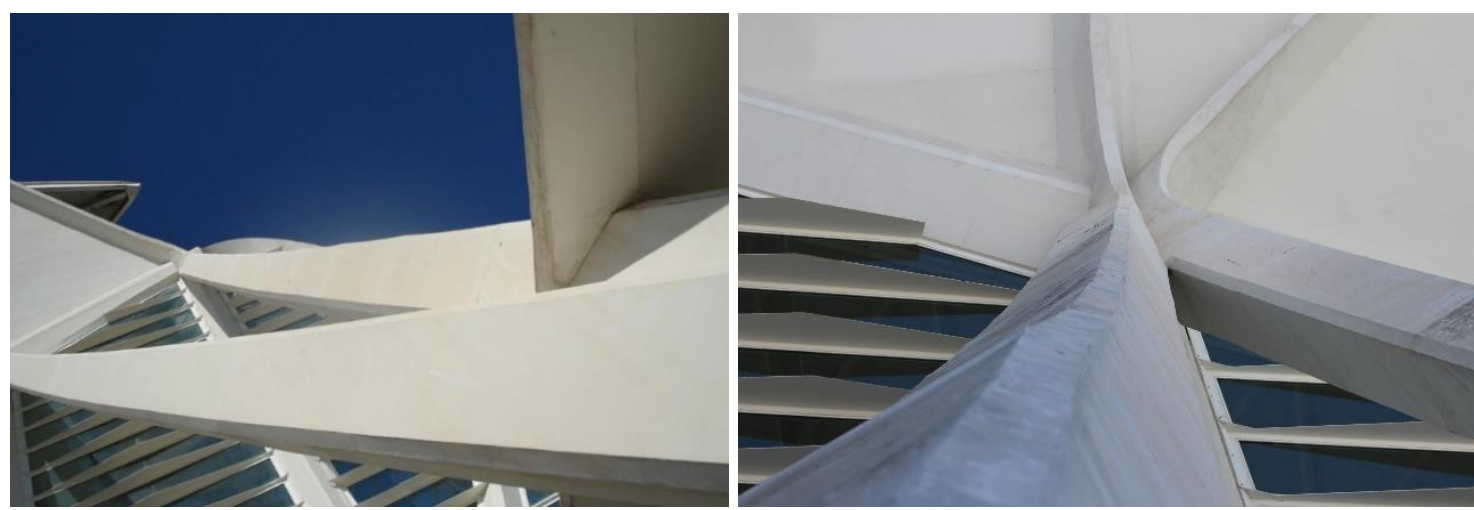

Fig.19. Deformation of columns at front and rear of the building.

\subsection{Repairs carried out}

After the successive visits authors did, many local repairs were seen to have been carried out in form of patching with mortar. Fig.20 shows some examples on concrete surfaces, others can be seen on inter-column joints in Fig.21, while Fig.22 shows a view of mortar patches on columns. However, some of these repairs have not been effective, since the mortar applied has become separated from the concrete surface.
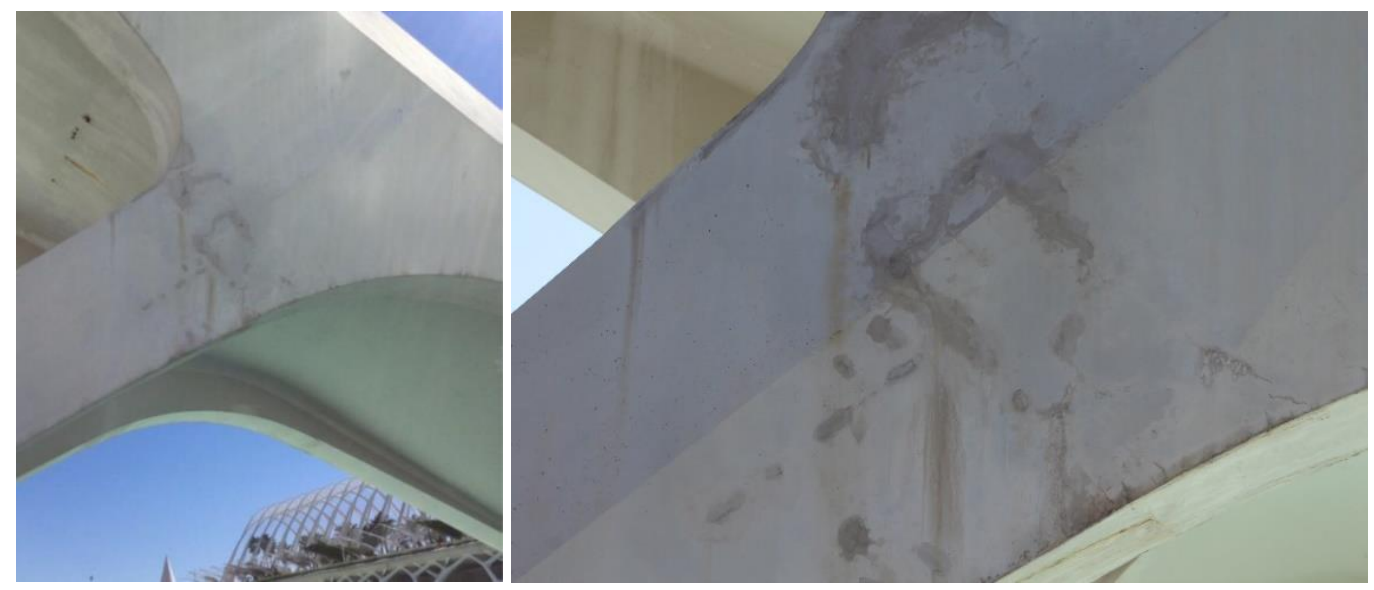

Fig. 20. Patching of concrete surfaces 


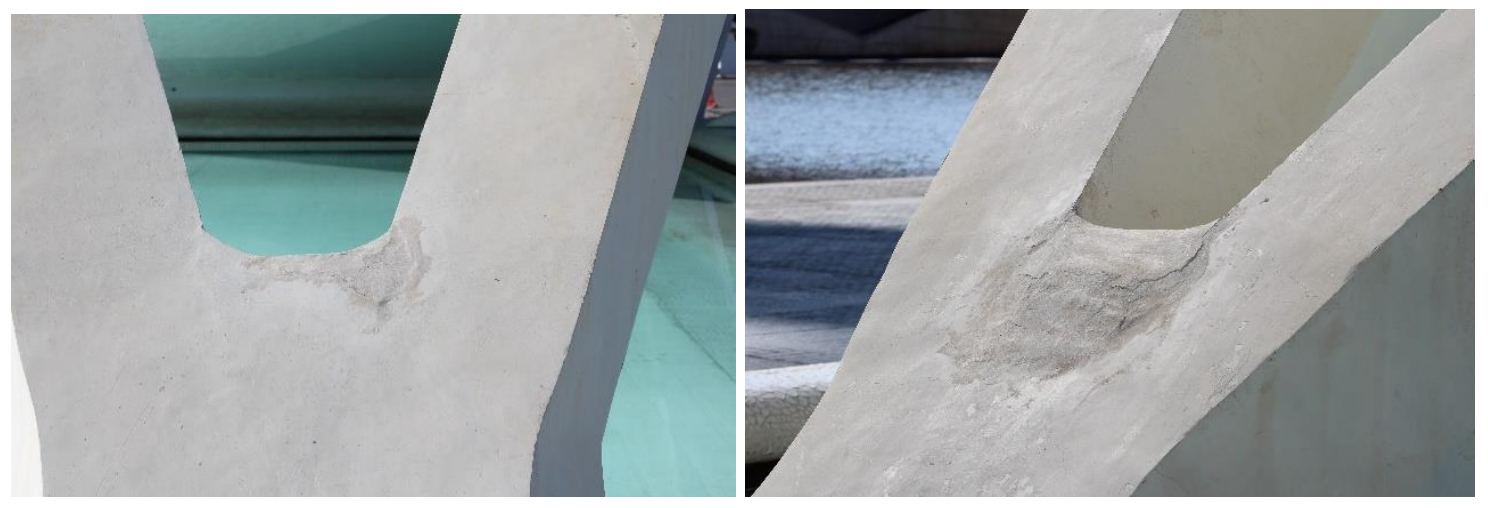

Fig. 21. Repairs with mortar on inter-column joint

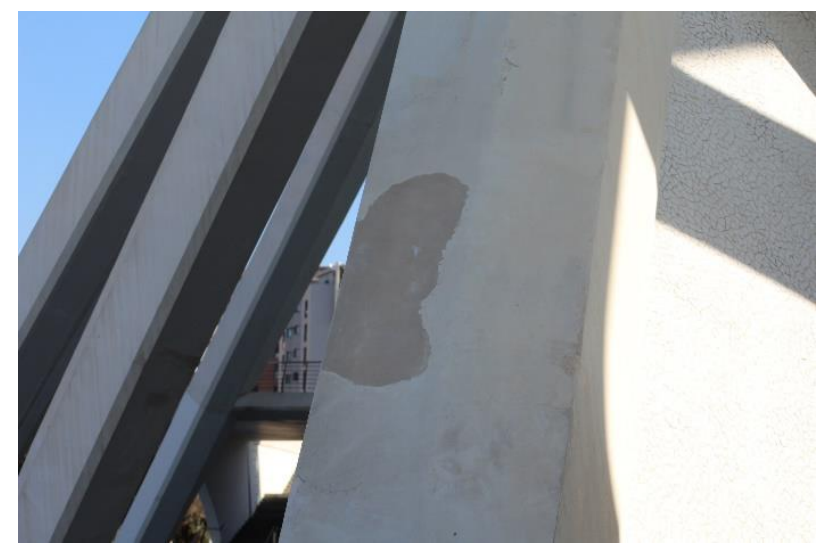

Fig. 22. Mortar patches on columns

\section{Conclusions}

The study of actual cases of failure has been shown to be a useful tool for training specialists in structural design and calculations. This paper has described the experience employed by the Universitat Politècnica de València to instruct its students in the field of structural engineering. A series of teaching routes were defined to be followed by the students under the supervision of lecturers. One of the buildings included in the visits is the Príncipe Felipe Science Museum, one of the city of Valencia'a most emblematic buildings, whose structure presents a wide variety of damages and provides valuable experience in the study of damage mechanisms in concrete structures.

Taking advantage of the visits to the Príncipe Felipe Science Museum, the most significant defects observed were classified and described. These ranged from those derived from the 
behaviour of the concrete itself to those caused by the action of loads. There are also other types of damage that can be attributed to the presence of damp and pores on concrete surfaces. In some cases, corrosion was found in the reinforcement, which can produce peeling of the concrete cover or rust stains around the existing cracks.

\section{Acknowledgements}

The authors also wish to express their gratitude for the assistance and support received from their fellow lecturers of the Building, Pathology and Prefabricated Construction Teaching Unit: Pedro A. Calderón, Juan J. Moragues, Ignacio J. Payá, Teresa Pellicer, Ruth Arribas, César Lacuesta and Alejandro Marqués.

\section{References}

[1] N.J. Delatte, K.L. Rens, Forensics and Case Studies in Civil Engineering Education: State of the Art, J. Perform. Constr. Facil. 16 (2002) 98-109. doi:10.1061/(ASCE)08873828(2002)16:3(98).

[2] N.J. Delatte, P.A. Bosela, R. Sutton, J. Bagaka's, Implementing forensics and failures in the civil engineering curriculum, in: 4th Int. Conf. Forensic Eng. From Fail. to Underst., London, 2008.

[3] N. Delatte, Failure literacy in structural engineering, Eng. Struct. 32 (2010) 1952-1954. doi:10.1016/j.engstruct.2009.12.015.

[4] N. Delatte, An approach to forensic engineering education inthe USA, Proc. Inst. Civ. Eng. Forensic Eng. 165 (2012) 123-129.

[5] H. Petroski, To Forgive Design, The Belknap Press of Harvard University Press, Cambridge, Massachussets, 2012.

[6] H. Petroski, To engineer is human: The role of failure in succesful design, St. Martin's Press, New York, 1985.

[7] C. Pearson, N. Delatte, Ronan Point Apartment Tower Collapse and its Effect on Building 
Codes, J. Perform. Constr. Facil. 19 (2005) 172-177.

[8] C. Pearson, N. Delatte, Collapse of the Quebec Bridge , 1907, J. Perform. Constr. Facil. 20 (2006) 84-91.

[9] S. King, N.J. Delatte, Collapse of 2000 Commonwealth Avenue: Punching Shear Case Study, J. Perform. Constr. Facil. 18 (2004) 54-61. doi:10.1061/(ASCE)08873828(2004)18:1(54).

[10] W.G. Corley, P.F. Mlakar Sr., M.A. Sozen, C.H. Thornton, The Oklahoma city bombing: Summary and recommendations for multihazard mitigation, J. Perform. Constr. Facil. 12 (1998) 100-112.

[11] A. Kazemi-Moghaddam, M. Sasani, Progressive collapse evaluation of Murrah federal building following sudden loss of column G20, Eng. Struct. 89 (2015) 162-171. doi:10.1016/j.engstruct.2015.02.003.

[12] P.F. Mlakar Sr., W.G. Corley, M.A. Sozen, C.H. Thornton, The Oklahoma city bombing: Analysis of blast damage to the Murrah Building, J. Perform. Constr. Facil. 12 (1998) $113-119$.

[13] J.D. Osteraas, Murrah building bombing revisited: A qualitative assessment of blast damage and collapse patterns, J. Perform. Constr. Facil. 20 (2006) 330-335. doi:10.1061/(ASCE)0887-3828(2006)20:4(330).

[14] M.A. Sozen, C.. Thornton, W.G. Corley, P.F. Mlakar Sr., The Oklahoma city bombing: Structure and mechanisms of the Murrah Building, J. Perform. Constr. Facil. 12 (1998) 120-136. doi:10.1061/(ASCE)0887-3828(1998)12:3(120).

[15] D.E. Walshe, T.A. Wyatt, Bridge aerodynamics 50 years after Tacoma Narrows - part II: A new discipline world-wide, J. Wind Eng. Ind. Aerodyn. 40 (1992) 327-336.

[16] T.A. Wyatt, Bridge aerodynamics 50 years after Tacoma Narrows - part I: The Tacoma Narrows failure and after, J. Wind Eng. Ind. Aerodyn. 40 (1992) 317-326.

[17] M. Matsumoto, H. Shirato, T. Yagi, R. Shijo, A. Eguchi, H. Tamaki, Effects of aerodynamic interferences between heaving and torsional vibration of bridge decks: The 
case of Tacoma Narrows Bridge, J. Wind Eng. Ind. Aerodyn. 91 (2003) 1547-1557. doi:10.1016/j.jweia.2003.09.010.

[18] R.H. Plaut, Snap loads and torsional oscillations of the original Tacoma Narrows Bridge, J. Sound Vib. 309 (2008) 613-636. doi:10.1016/j.jsv.2007.07.057.

[19] W.G. Corley, Lessons learned on improving resistance of buildings to terrorist attacks, J. Perform. Constr. Facil. 18 (2004) 68-78. doi:10.1061/(ASCE)0887-3828(2004)18:2(68).

[20] Y. Omika, E. Fukuzawa, N. Koshika, H. Morikawa, R. Fukuda, Structural responses of World Trade Center under aircraft attacks, J. Struct. Eng. 131 (2005) 6-15. doi:10.1061/(ASCE)0733-9445(2005)131:1(6).

[21] M. Wang, P. Chang, J. Quintiere, A. Marshall, Scale modeling of the 96th floor of World Trade Center Tower 1, J. Perform. Constr. Facil. $21 \quad$ (2007) 414-421. doi:10.1061/(ASCE)0887-3828(2007)21:6(414).

[22] A. Irfanoglu, C.M. Hoffmann, Engineering perspective of the collapse of WTC-I, J. Perform. Constr. Facil. 22 (2008) 62-67. doi:10.1061/(ASCE)0887-3828(2008)22:1(62).

[23] K. Miamis, A. Irfanoglu, M.A. Sozen, Dominant factor in the collapse of WTC-1, J. Perform. Constr. Facil. 23 (2009) 203-208. doi:10.1061/(ASCE)CF.1943-5509.0000014.

[24] J.J. del Coz Díaz, J.M. Adam, A. Lozano Martínez-Luengas, F.P. Alvarez Rabanal, Collapse of a Masonry Wall in an Industrial Building : Diagnosis by Numerical Modeling, J. Perform. Constr. Facil. 27 (2013) 65-76. doi:10.1061/(ASCE)CF.1943-5509.0000310.

[25] J.J. del Coz Díaz, A.L. Martínez-Luengas, J.M. Adam, A. Martín Rodríguez, Non-linear hygrothermal failure analysis of an external clay brick wall by FEM - A case study, Constr. Build. Mater. 25 (2011) 4454-4464. doi:10.1016/j.conbuildmat.2010.12.039.

[26] J.G. Ruiz-Pinilla, J.M. Adam, R. Pérez-Cárcel, J. Yuste, J.J. Moragues, Learning from RC building structures damaged by the earthquake in Lorca, Spain, in 2011, Eng. Fail. Anal. 68 (2016) 76-86. doi:10.1016/j.engfailanal.2016.05.013.

[27] N. Augenti, F. Parisi, Learning from construction failures due to the 2009 L'Aquila, Italy, earthquake, J. Perform. Constr. Facil. 24 (2010) 536-555. doi:10.1061/(ASCE)CF.1943- 
5509.0000122.

[28] S. Ivorra, F.J. Pallarés, J.M. Adam, Dynamic behaviour of a modern bell tower - A case study, Eng. Struct. 31 (2009) 1085-1092. doi:10.1016/j.engstruct.2009.01.002.

[29] J.M. Adam, J.D. Moreno, M. Bonilla, T.M. Pellicer, Classification of damage to the structures of buildings in towns in coastal areas, Eng. Fail. Anal. 70 (2016) 212-221. doi:10.1016/j.engfailanal.2016.09.004.

[30] G. López-Patiño, J.M. Adam, P. Verdejo Gimeno, G. Milani, Causes of damage to industrial brick masonry chimneys, Eng. Fail. Anal. 74 (2017) 188-201. doi:10.1016/j.engfailanal.2017.01.014.

[31] P.A. Calderón, J.M. Adam, I. Payá-Zaforteza, Failure analysis and remedial measures applied to a RC water tank, Eng. Fail. Anal. 16 (2009) 1674-1685. doi:10.1016/j.engfailanal.2008.12.004.

[32] N. Augenti, F. Parisi, Buckling analysis of a long-span roof structure collapsed during construction, J. Perform. Constr. Facil. 27 (2013) 77-88. doi:10.1061/(ASCE)CF.19435509.0000302.

[33] M. Betti, G. Bartoli, M. Orlando, Evaluation study on structural fault of a Renaissance Italian palace, Eng. Struct. 32 (2010) 1801-1813. doi:10.1016/j.engstruct.2010.03.001.

[34] M. Buitrago, J.J. Moragues, P.A. Calderón, J.M. Adam, Structural failures in cast-in-place RC building structures under construction, in: A.S.H. Makhlouf, M. Aliofkhazraei (Eds.), Handb. Mater. Fail. Anal. with Case Stud. from Constr. Ind. Vol. 6, 1st ed, ButterworthHeinemann, Elsevier, 2018: p. 560. doi:10.1016/ B978-0-08-101928-3.00008-2.

[35] G. Bartoli, M. Betti, Cappella dei Principi in Firenze, Italy: Experimental analyses and numerical modeling for the investigation of a local failure, J. Perform. Constr. Facil. 27 (2013) 4-26. doi:10.1061/(ASCE)CF.1943-5509.0000315.

[36] R. Bayuaji, M. Sigit Darmawan, N.A. Husin, R.B. Anugraha, A. Budipriyanto, Corrosion damage assessment of a reinforced concrete canal structure of power plant after 20 years of exposure in a marine environment: A case study, Eng. Fail. Anal. 84 (2018) 287-299. 
doi:10.1016/j.engfailanal.2017.11.014.

[37] M. Mosoarca, A.I. Keller, C. Petrus, A. Racolta, Failure analysis of historical buildings due to climate change, Eng. Fail. Anal. 82 (2017) 666-680. doi:10.1016/j.engfailanal.2017.06.013.

[38] I.O. Otunniyi, D.T. Oloruntoba, S.O. Seidu, Metallurgical analysis of the collapse of a telecommunication tower : Service life versus capital costs tradeoffs, Eng. Fail. Anal. 83 (2018) 125-130. doi:10.1016/j.engfailanal.2017.09.018.

[39] C. Vatansever, E. Seçkin, G. Yazici, Snow induced collapse of hail protection canopies, Eng. Fail. Anal. 79 (2017) 186-197. doi:10.1016/j.engfailanal.2017.04.032.

[40] J. Krentowski, T. Chyzy, P. Dunaj, Sudden collapse of a 19th-century masonry structure during its renovation process, Eng. Fail. Anal. 82 (2017) 540-553. doi:10.1016/j.engfailanal.2017.04.010.

[41] T.D. Stark, R. Benekohal, L.A. Fahnestock, J.M. LaFave, J. He, C. Wittenkeller, I-5 Skagit River Bridge Collapse Review, J. Perform. Constr. Facil. 30 (2016) 1-12. doi:10.1061/(ASCE)CF.1943-5509.0000913.

[42] B. Shrestha, H. Hao, Building Pounding Damages Observed during the 2015 Gorkha Earthquake, J. Perform. Constr. Facil. 32 (2018) 1-10. doi:10.1061/(ASCE)CF.19435509.0001134.

[43] J. Bilcik, R. Sonnenschein, I. Holly, Causes of and Responsibilities for an Excessive Amount of Leaking Cracks in a Massive Concrete Mat Foundation, J. Perform. Constr. Facil. 32 (2018) 1-8. doi:10.1061/(ASCE)CF.1943-5509.0001130.

[44] W.D. Wang, Q. Li, Y. Hu, J.W. Shi, C.W.W. Ng, Field Investigation of Collapse of a 13Story High-Rise Residential Building in Shanghai, J. Perform. Constr. Facil. 31 (2017) 19. doi:10.1061/(ASCE)CF.1943-5509.0001005.

[45] L.E. Yamin, J.F. Correal, J.C. Reyes, F. Ramirez, R. Rincón, A.I. Hurtado, J.F. Dorado, Sudden Collapse of the 27-Story Space Building in Medellin, Colombia, J. Perform. Constr. Facil. 32 (2018) 1-13. doi:10.1061/(ASCE)CF.1943-5509.0001148. 
[46] Príncipe Felipe Science Museum. http://www.cac.es/en/Museu-de-les-Ciencies/museude-les-ciencies/conoce-el-museu.html (accessed April 6, 2018) 